\title{
The intellectual structure of behavioral strategy: a bibliometric study
}

\author{
Santiago Urío \\ Department of Business Management, Universidad Pontificia Comillas, ICADE, Madrid, Spain \\ https://orcid.org/0000-0001-6458-2220
}

Raquel Redondo

Department of Quantitative Methods, Universidad Pontificia Comillas, ICADE, Madrid, Spain

https://orcid.org/0000-0002-6534-0271

\section{Diana Gavilan}

Department of Marketing, Complutense University of Madrid, Madrid, Spain

https://orcid.org/0000-0002-5293-779X

\begin{abstract}
Behavioral strategy is a relatively new subfield of strategic management and yet its roots go back to the origins of the discipline. Its rapid growth over the last few years, the interest created in the research community, and the intrinsically diversified approaches call for organization of the intellectual structure developed by scholars. This paper aims to provide the intellectual structure of the subject based on the published research for the entire period covered by the Social Science Citation Index (SSCI) Database. By using bibliometric and data analytic techniques, we determine the key works in the development of the subfield, the groups that determine the conceptual contributions and the bridging works that provide the common bond between them. To achieve this, we have used co-citation analysis to capture relationships. It is followed by multidimensional scaling (MDS) and a principal component factor analysis (PCFA) for displaying the groups of works that constitute the different lines of research. The study offers useful insights in the discipline and conclusions for future developments in the subject for researchers and practitioners alike.
\end{abstract}

\section{Keywords}

behavioral strategy, strategic management, literature review, co-citation analysis, bibliometrics.

\section{Introduction}

Strategic management deals with the major initiatives taken by general managers on behalf of owners, involving utilization of resources to enhance the performance of firms in their external environments (Nag, R., Hambrick, D. C., \& Cheng, M., 2007). Despite its development over more than a century, this field of knowledge is relatively young, yet immature and very fragmented, with several open lines of research (Nag et al., 2007; Nerur, S. P., Rasheed, A. A., \& Natarajan, V., 2008; Pettigrew, A., Thomas, H., \& Whittington, R., 2002; Volberda, 2004). Attempts have been made by a few authors to structure and summarize the main streams on the subject (Guerras-Martín, L. Á, Madhok, A., \& Montoro-Sánchez, Á., 2014; Nerur et al., 2008; Ramos-Rodríguez \& RuízNavarro, 2004).

One of the most recent and promising lines of research in strategic management works on the influence of cognitive processes in decision making. It encompasses several approaches to strategy and business management that consider the behavioral, non-rational character of individuals and organizations when making business decisions (Bromiley, 2005). This consideration becomes more important when looking at the two main stages of the strategic management process, formulation, and 
implementation, both entailing a high degree of human decision making.

Since the last decade of last century, both academics and practitioners have realized the need to fully explore the opportunities that highlighting the behavioral component of decision making could offer to the development and implementation of business strategies. However, behavioral research in strategic management has been lagging behind other disciplines (Lovallo \& Sibony, 2010; Powell, T. C., Lovallo, D., \& Fox, C. R., 2011) such as economy (Tversky \& Kahneman, 1974), finance (Thaler, 2005), and marketing (Dobni, B., Dobni, D., \& Luffman, G., 2001).

In the initial stages, when looking at the behavioral influence in the strategic management process, the researchers focused on specific areas often unconnected to each other (Camerer \& Lovallo, 1999; Felin \& Foss, 2005; Levinthal \& March, 1993; Ocasio, 1997). It was clearly necessary to stand back and gain perspective. A key step in structuring the knowledge and research and providing the basis for a conceptual unity to the approach was taken by Powell et al., (2011), who coined and defined the term "behavioral strategy". Since then, it has been consolidated as a promising field within the strategic management discipline and several researchers have published studies contributing to its rapid development.

Despite the fact that literature reviews for the purpose of structuring a discipline of knowledge intellectually are mostly carried out once that discipline has reached a certain level of maturity, at other times they also address new or emerging topics that would benefit from a holistic conceptualization and synthesis of the literature (Ramdhani, A., Ramdhani, M. A., \& Amin, A. S., 2014). The latter initiative is particularly required when the complexity caused by the confluence of different fields of knowledge in a new discipline requires an overall view so as not to lose perspective. This is the case of the behavioral approach in the development of business strategies, as it needs contribution from such disparate areas as psychology, sociology, and organizational management, as well as some of the main research streams of strategic management itself.

To the best of our knowledge, this need has not been addressed using a systematic bibliometric methodology to draw upon the avenues of different disciplines that are converging and developing the discipline. The attempts, previously mentioned, to delineate the intellectual structure of strategic management had not yet identified behavioral strategy as an emergent line of research within the field. Other researchers have carried out extensive narrative literature reviews as part of their work, but their aim was to support their arguments rather than study the topic systematically (Bromiley, 2005; Powell et al., 2011).

To cover this gap, we have conducted a systematic quantitative review. It is systematic because we have used a citation and co-citation analysis methodology, which selects the literature in a way that is explicit, transparent, and reproducible, avoiding biases and subjectivity (Snyder, 2019). The objective of this article is to show the most influential works of the different research streams that are contributing to the development of the behavioral vision of strategic management. It achieves this by identifying the most influential research works and their contributions, grouping them so as to display their structure and development.

This paper is not a substitute for exhaustive study of the content, but rather contributes to assessing the degree of influence and relationships between each of the works and the different fields of knowledge they come from, on objective parameters. The results will help scholars develop this line of research further by clarifying the confluence of the disciplines, through indicating the building blocks used by researchers. This approach will also help practitioners by clearly identifying and delineating the foundations of the intellectual structure of the discipline.

The article is organized into three sections. The first is a review of the methodology in general and its application in this case. The second presents and analyzes the results of the study (describing the different analyses according to the final scheme). The third summarizes the main conclusions obtained, possible limitations, and future research.

\section{Methodology}

We have chosen citation analysis for the review because it is the technique most accepted in academia to measure the quality and influence of scholarly publications (Cole \& Cole, 1971). The assumption is that the works, and authors cited by researchers who explicitly devote their effort to the development of the field, are those that have influenced them to build their contributions (Smith, 1981). This methodology therefore allows the definition of the key influencers in the discipline and it is an objective and powerful tool to systematically analyze a large number of works. 
However, the establishment of relationships between works and therefore of the intellectual structure of the discipline requires going beyond mere citation. To achieve this, we have used cocitation analysis to capture relationships. It is followed by multidimensional scaling (MDS) and a principal component factor analysis (PCFA) for displaying the groups of works that constitute the different lines of research.

\subsection{Methodology used in this paper}

In the case of behavioral strategy, finding the key authors systematically is particularly difficult because of its essential interdisciplinarity. The approaches of seminal articles and the keywords used to position them are not homogeneous. To overcome this difficulty, and to obtain a representative collection of behavioral strategy research, we have carried out a three-step process which allowed us to perform a wide visual sweep of the discipline: first, we focused on the works which explicitly use the term "behavioral strategy", second, we used a wide-angle lens to examine the works cited by studies selected in the first step, and finally, we used co-citation technique to reduce the focus distance and raise the intellectual structure (see Figure 1).

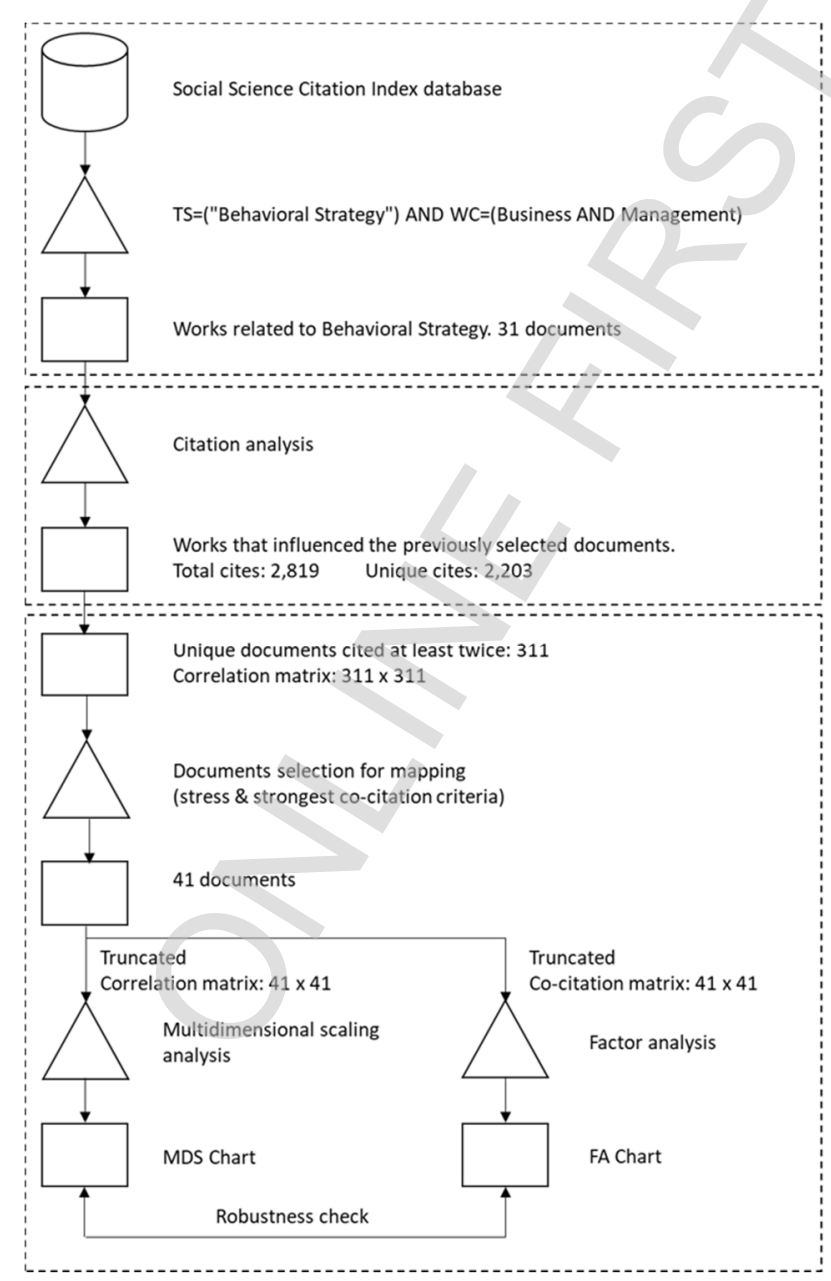

Step 1

Step 2

Step 3

Figure 1: Research steps

Source: the author's

In the first step, we retrieved an initial group of papers from the Social Science Citation Index database from all sources and the time period available, using "behavioral strategy" as the search string. To make sure we were working with the right discipline, the results were filtered by the categories "business" and "management". This search provided 31 documents. The limited number of publications located is due to the fact that the term "behavioral strategy" has gained currency in the field only recently. 
In the second step, we retrieved the 2,203 unique cited documents from the previous extraction to perform a citation analysis and gain a view of the literature that influenced them. Not all these cited documents were related to behavioral strategy, as researchers cite in their works documents that support all the aspects covered.

In the third step, we examined the co-citations and their frequency as a proxy for the commonality of the citations around the behavioral strategy topic. The assumption was that frequently co-cited papers represent the key concepts, methods or experiments in the field (Small, 1973). From the 2,203 cited documents of the previous step, we got a co-citation matrix well above four million cells. In order to refine the selection and make the cocitation matrix manageable, we reduced this matrix by selecting the 311 most frequently (at least twice) cited papers (Bergh, D. D., Perry, J., \& Hanke, R., 2006; García-Lillo, F., Úbeda-García, M., \& Marco-Lajara, B., 2016; Ramos-Rodríguez \& Ruíz-Navarro, 2004). This is well over the number selected by other researchers, precluding omission of papers that could be significant and reaching the computational limit of the software used (SPSS, v26). Following Ramos-Rodriguez and RuizNavarro (2004), we then used r-Pearson correlation as a measure of similarity between documents and considered main diagonal as missing data. Once the correlation matrix was determined, we applied multidimensional scaling technique (MDS) using stress as a goodness of fit index. As stress value depends on the number of documents and their original configuration, we had to select the number of papers to map. If the number of papers is between 20 and 50, the stress measure is optimal and allows a readable map in a reduced space, providing a clear graphical representation and containing an adequate number of works to enable the intellectual structure of the field to emerge (Ramos-Rodríguez \& Ruíz-Navarro, 2004).

To make that selection, we determined the strongest co-citation as the maximum frequency a paper was co-cited with any other. For example, Gavetti, Greve, Levinthal and Ocasio's (2012) strongest co-citation was 8 , the number of co-cites with Powell, Lovallo and Fox (2011), whereas it was co-cited fewer times with other papers.

Strongest co-citation $($ paper $(i))=\max (k)$ so that co-citation (paper $(i)$, paper $(j))=k$ for certain $j=1,2, \ldots 2044$
We explored both the number of papers and the number of total co-citations involved, considering those papers with strongest co-citations, where $\mathrm{s}=$ $1,2, \ldots, 8$, as 8 was the maximum number of cocitations linking two particular papers in the cocitation matrix. Table 1 shows the results of this exploration.

Table 1 Number of papers per co-citation level.

\begin{tabular}{c|c|c}
\hline $\begin{array}{c}\text { strongest } \\
\text { co-citation } \\
\text { considered }\end{array}$ & $\begin{array}{c}\text { number } \\
\text { of } \\
\text { papers }\end{array}$ & $\begin{array}{c}\text { number } \\
\text { of } \\
\text { co-citations }\end{array}$ \\
\hline 1 & 2.044 & 152.346 \\
\hline 2 & 303 & 19.556 \\
\hline 3 & 99 & 5.159 \\
\hline 4 & 41 & 1.505 \\
\hline 5 & 11 & 180 \\
\hline 6 & 5 & 48 \\
\hline 7 & 3 & 21 \\
\hline 8 & 3 & 21 \\
\hline & & Source: the author's
\end{tabular}

Accordingly, we chose the 41 documents that presented a frequency of 4 with at least one other document in the co-citation matrix.

Finally, we conducted a factor analysis on the truncated co-citation matrix corresponding to the 41 selected works as a robustness check and grouping them to map the intellectual structure of the field.

\section{Results and discussion}

\subsection{Initial extraction analysis}

We first conducted an analysis of the 31 extracted from the SSCI database using "behavioral strategy" as the keyword (see Figure 1). Table 2 shows the initial list of top works ranked by their year of publication and number of citations. In spite of the large number of top ranked citations, the number of entries is small, as the extraction was based on a keyword/term coined in 2011. Thus, all documents retrieved are dated within the period 2011-2021. 
Table 2 List of works ranked by year and number of cites

\begin{tabular}{|c|c|c|c|}
\hline No. & Authors & Cites & Local cites \\
\hline \multicolumn{4}{|c|}{2011} \\
\hline 1 & Powell, T.C., Lovallo. D., Fox, C.R. & 260 & 19 \\
\hline 2 & Hodgkinson, G.P., Healey, M.P. & 202 & 7 \\
\hline \multicolumn{4}{|c|}{ (1) } \\
\hline 3 & Barney, J., Felin, T. & 176 & 1 \\
\hline 4 & Reitzig, M, Sorenson, O. & 37 & 2 \\
\hline \multicolumn{4}{|c|}{2014} \\
\hline 5 & Powell, T.C. & 16 & 2 \\
\hline 6 & Hodgkinson, G.P., Healey, M.P. & 18 & 1 \\
\hline \multicolumn{4}{|c|}{2015} \\
\hline 7 & Woodside, A.G. & 12 & 0 \\
\hline 8 & Maitland, E., Sammartino, A. & 42 & 0 \\
\hline 9 & Reitzig, M., Maciejovsky, B. & 17 & 1 \\
\hline \multicolumn{4}{|c|}{2016} \\
\hline 10 & Artinger, S., Powell, T.C. & 21 & 2 \\
\hline 11 & Reilly, G., Souder, D., Ranucci, R. & 16 & 0 \\
\hline 12 & Schillebeeckx, S.J.D., Chaturvedi, S., George, G., King, Z. & 9 & 0 \\
\hline \multicolumn{4}{|c|}{2017} \\
\hline 13 & Elfenbein, D.W., Knott, A.M., Croson, R. & 3 & 0 \\
\hline 14 & Luoma, J., Ruutu, S., King, A.W., Tikkanen, H. & 5 & 0 \\
\hline 15 & Sibony, O., Lovallo, D., Powell, T.C. & 10 & 0 \\
\hline 16 & Healey M,P., Hodgkinson, G.P. & 7 & 0 \\
\hline 17 & Powell, T.C. & 9 & 0 \\
\hline 18 & Meissner, P., Wulf, T. & 4 & 0 \\
\hline 19 & Bardolet, D., Brown, A., Lovallo, D. & 1 & 0 \\
\hline 20 & Souder, D., Bromiley, P. & 2 & 0 \\
\hline 21 & Bettis, R.A. & 7 & 0 \\
\hline 22 & Levine, S.S., Bernard, M., Nagel, R. & 11 & 1 \\
\hline \multicolumn{4}{|c|}{2018} \\
\hline 23 & Ocasio, W., Laamanen, T., Vaara, E. & 17 & 0 \\
\hline 24 & Tarakci, M., Ates, N.Y., Floyd, S.W., Ahn, Y., Wooldridge, B. & 7 & 0 \\
\hline 25 & Rhee, L., Leonardi, P.M. & 7 & 0 \\
\hline 26 & Luoma, J., Falk, T., Totzek, D., Tikkanen, H., Mrozek, A. & 3 & 0 \\
\hline 27 & Osiyevskyy, O., Dewald, J. & 1 & 0 \\
\hline \multicolumn{4}{|c|}{2019} \\
\hline 28 & Mohliver, A. & 2 & 0 \\
\hline 29 & Di Stefano, G., Gutierrez, C., & 1 & 0 \\
\hline 30 & Du, X.J., Li, M., Wu, B. & 0 & 0 \\
\hline \multicolumn{4}{|c|}{ 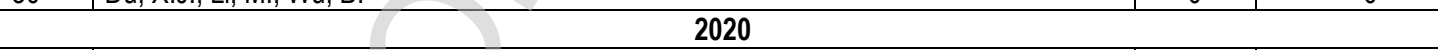 } \\
\hline 31 & Porck, J.P., van Knippenberg, D., Tarakci, M., Ates, N.Y., Groenen, P.J.F. et al. & 1 & 0 \\
\hline
\end{tabular}

The list of institutions shows a significant involvement of European universities using and supporting the behavioral strategy research term in the field. Of the top eleven institutions with two or more works, nine are European, with an Australian and an American university completing the list (see Table 3). In addition to the strength in cognitive psychology development, particularly in British institutions, this fact points to a higher acceptance of the term "behavioral strategy" by European academia when compared with researchers from other geographies.
Table 3 List of Institutions ranked by number of works (with Total Local and Total Global Cited Score.

\begin{tabular}{l|c|c|c}
\hline Institution & Recs & TLCS & TGCS \\
\hline Univ Oxford & 5 & 23 & 316 \\
\hline Aalto Univ & 3 & 0 & 25 \\
\hline Univ Manchester & 3 & 8 & 227 \\
\hline Univ Sydney & 3 & 19 & 271 \\
\hline Bilkent Univ & 2 & 0 & 8 \\
\hline Erasmus Univ & 2 & 0 & 8 \\
\hline HEC Paris & 2 & 0 & 11 \\
\hline Tilburg Univ & 2 & 0 & 8 \\
\hline Univ Connecticut & 2 & 0 & 18 \\
\hline Univ Vienna & 2 & 3 & 54 \\
\hline Univ Warwick & 2 & 8 & 220 \\
\hline
\end{tabular}




\subsection{The most influential works in behavioral strategy}

In the second step of the process, we conducted a citation analysis of the works cited in the records initially extracted. Table 4 shows the top cited works (up to 5 times). The top ten positions look at different aspects of firms' behavior which should be considered from a strategic management point of view.

There is a first group of authors which belong to the early roots of the behavioral theory of the firm, found at the second position, in Cyert and March (1963) together with sixth placed March and Simon (1958). The three authors led the socalled Carnegie School which, working in the field of organizational behavior, questioned rationality in human decision making and developed the concept of bounded rationality. This approach, which applied the cognitive research of psychology in organizations for the first time, was the basis for behavioral research extended to other economic and business fields.

Grounded in the developments of the first group, Kahneman and Tversky (1979) article is seminal for behavioral economics which had a significant influence in strategic management developments. In a later article, Kahneman and Lovallo (1993), analyze the biases in risk taking documented in psychological research and the implications for decision making in organizations. The influence of heuristics has been one of the main subjects of research in organizational behavior (Loock \& Hinnen, 2015).

Working on the path of behavioral decisionmaking and psychological biases, there were a group of works dealing with different aspects of their influence in strategic management. Camerer and Lovallo (1999) explore the overconfidence bias in individuals and organizations, Levinthal and March's (1993) the myopia of learning as an early warning in strategic management research based on rational grounds and Ocasio's (1997) focuses on the attention-based view of the firm.

Finally, in this time travel along the most cited articles, there is a group of works stressing behavioral aspects as key for strategy definition and implementation as the source of competitive advantage. At the top of the list is the article that defines the term "behavioral strategy" (Powell et al., 2011). This was the lead article and introduction to the Strategic Management Journal special issue on the "Psychological foundations of strategic management". Two more articles from the same issue are in top positions, Levinthal (2011) and Hodgkinson and Healey (2011) marking the actual birth of the subfield. Gavetti (2012) joins this group one year later signaling that superior opportunities are cognitively distant.

Table 4 List of top cites.

\begin{tabular}{|c|c|c|}
\hline Rank & $\#$ & Work \\
\hline 1 & 23 & Powell, T. (2011) \\
\hline 2 & 11 & Cyert, R. (1963) \\
\hline 3 & 9 & Levinthal, D. (2011) \\
\hline 4 & 8 & Camerer, C. (1999) \\
\hline 5 & 8 & Gavetti, G. (2012) \\
\hline 6 & 7 & Levinthal, D. (1993) \\
\hline 7 & 7 & Kahneman, D. (1979) \\
\hline 8 & 7 & Kahneman, D. (1993) \\
\hline 9 & 7 & March, J. (1958) \\
\hline 10 & 7 & Ocasio, W. (1997) \\
\hline 11 & 7 & Teece, D. (2007) \\
\hline 12 & 6 & Hambrick, D. (1984) \\
\hline 13 & 6 & Hodgkinson, G. (2008) \\
\hline 14 & 6 & Hodgkinson, G. (2011) \\
\hline 15 & 6 & Simon, H. (1947) \\
\hline 16 & 6 & Zajac, E. (1991) \\
\hline 17 & 6 & Zollo, M. (2002) \\
\hline 18 & 5 & Gary, M. (2012) \\
\hline 19 & 5 & Gavetti, G. (2005) \\
\hline 20 & 5 & Gavetti, G. (2007) \\
\hline 21 & 5 & Huy, Q. (1999) \\
\hline 22 & 5 & Kahneman, D. (1982) \\
\hline 23 & 5 & Lovallo, D. (2012) \\
\hline 24 & 5 & Porter, M. (1980) \\
\hline 25 & 5 & Teece, D. (1997) \\
\hline 26 & 5 & Thaler, R. (2008) \\
\hline 27 & 5 & Tversky, A. (1974) \\
\hline 28 & 5 & Schwenk, C. (1984) \\
\hline
\end{tabular}

\subsection{Strategic management vs. behavioral strategy influencers}

As an extension of the previous analysis, we have compared our ranking of the most influential works in the behavioral strategy field with the parent discipline of strategic management. For the purpose we first used Ramos-Rodríguez and RuizNavarro's (2004) ranking of the most cited strategic management works for the period 1980-2000 (see Table 5). As this research ends with the century, we added the comparison with the study of Furrer, Thomas and Goussevskaia (2008) which extends the research period to 2005, but focuses only on the articles published in four of the leading journals of strategy (AMJ, AMR, ASQ, and SMJ) (see Table 6). The comparison shows the intersection of the two sets of influential works for the field and the discipline. Although their study periods ended 
more than fourteen years ago, it is a valuable analysis, as most of the cited works in behavioral strategy fall within the research periods. The results show a very limited intersection between the lists, pointing to the fact that even if we consider behavioral strategy to be a field within the discipline of strategic management, it is at the intersection of a varied mix of disciplines and rather than a branch it should be considered a complement that nurtures the current and future development of the discipline.

Table 5 Ranking comparison strategic management vs behavioral strategy

\begin{tabular}{|c|c|c|}
\hline Rank SM & Work & Rank BS \\
\hline 1 & Porter (1980) & 18 \\
\hline 2 & Rumelt (1974) & - \\
\hline 3 & Porter (1985) & 338 \\
\hline 4 & Chandler (1962) & 338 \\
\hline 5 & Williamson (1975) & - \\
\hline 6 & Nelson and Winter (1982) & 29 \\
\hline 7 & Pfeffer and Salancik (1978) & - \\
\hline 8 & Miles and Snow (1978) & 338 \\
\hline 9 & Cyert and March (1963) & 2 \\
\hline 10 & Thompson (1967) & - \\
\hline 11 & Hofer and Schendel (1978) & 338 \\
\hline 12 & Wernerfelt (1984) & 29 \\
\hline 13 & Barney (1991) & 70 \\
\hline 14 & Lawrence and Lorsch (1967) & 70 \\
\hline 15 & Andrews (1971) & 338 \\
\hline 16 & Penrose (1959) & 338 \\
\hline 17 & Ansoff (1965) & 338 \\
\hline 18 & Williamson (1985) & - \\
\hline 19 & Scherer (1980) & 338 \\
\hline 20 & Quinn (1980) & - \\
\hline 21 & Prahalad and Hamel (1990) & 338 \\
\hline 22 & Dierickx and Cool (1989) & - \\
\hline 23 & Jensen and Meckling (1976) & 134 \\
\hline 24 & Weick (1969) & - \\
\hline 25 & March and Simon (1958) & 6 \\
\hline 26 & Mintzberg (1978) & - \\
\hline 27 & Bower (1970) & 29 \\
\hline 28 & Child (1972) & - \\
\hline 29 & Aldrich (1979) & - \\
\hline 30 & Barney (1986) & 70 \\
\hline 31 & Hannan and Freeman (1984) & - \\
\hline 32 & Lippman and Rumelt (1982) & 70 \\
\hline 33 & Mintzberg et al. (1976) & 338 \\
\hline 34 & Burns and Stalker (1961) & - \\
\hline 35 & Cohen and Levinthal (1990) & 70 \\
\hline 36 & Hambrick and Mason (1984) & 12 \\
\hline 37 & Rumelt (1984) & 338 \\
\hline 38 & Buzzell et al. (1975) & - \\
\hline 39 & Tushman and Anderson (1986) & - \\
\hline 40 & Hannan and Freeman (1977) & - \\
\hline
\end{tabular}

Ruíz-Navarro, 2004
Some works have been very influential for both behavioral strategy and strategic management: March and Simon (1958), Cyert and March (1963) and Porter (1980). The first two, the cornerstones of the behavioral theory of the firm, are ranked among the top ten in behavioral strategy and the top twenty-five in strategic management. The last is the most influential in strategic management and ranks eighteenth in behavioral strategy.

Table 6 Ranking comparison strategic management vs behavioral strategy

\begin{tabular}{|c|c|c|}
\hline Rank SM & Work & Rank BS \\
\hline 1 & Barney (1991b) & 56 \\
\hline 2 & Cohen and Levinthal (1990) & 56 \\
\hline 3 & Teece et al. (1997) & 17 \\
\hline 4 & Wernerfelt (1984) & 29 \\
\hline 5 & Nahapiet and Ghoshal (1998) & 312 \\
\hline 6 & Powell et al. (1996) & - \\
\hline 7 & Dyer and Singh (1998) & 119 \\
\hline 8 & Grant (1996) & 119 \\
\hline 9 & Uzzi (1997) & - \\
\hline 10 & Peteraf (1993) & 312 \\
\hline 11 & Eisenhardt and Martin (2000) & 29 \\
\hline 12 & Dierickx and Cool (1989b) & - \\
\hline 13 & Williamson (1991) & - \\
\hline 14 & Tushman and Anderson (1986) & - \\
\hline 15 & Gulati (1995) & - \\
\hline 16 & Szulanski (1996) & 119 \\
\hline 17 & Amit and Schoemaker (1993) & 56 \\
\hline 18 & Leonard-Barton (1992) & 312 \\
\hline 19 & Hambrick and Mason (1984) & 11 \\
\hline 20 & Eisenhardt (1989a) & 312 \\
\hline 21 & Ring and Van de Ven (1994) & - \\
\hline 22 & Hamel (1991) & - \\
\hline 23 & Gulati (1998) & - \\
\hline 24 & Levinthal and March (1993) & 5 \\
\hline 25 & Eisenhardt and Tabrizi (1995) & - \\
\hline 26 & Oliver (1991) & - \\
\hline 27 & Ouchi (1980) & - \\
\hline 28 & Kogut (1988) & - \\
\hline 29 & Lane and Lubatkin (1998) & - \\
\hline 30 & Eisenhardt (1989b) & 56 \\
\hline 31 & Ring and Van de Ven (1992) & - \\
\hline 32 & Suchman (1995) & - \\
\hline 33 & Spender (1996) & 312 \\
\hline 33 & Doz (1996) & - \\
\hline 35 & Conner (1991b) & - \\
\hline 36 & Mitchell et al. (1997) & - \\
\hline 37 & Parkhe (1993) & - \\
\hline 38 & Powell (1995) & - \\
\hline 39 & Gulati et al. (2000) & - \\
\hline 40 & Henderson and Cockburn (1994) & 312 \\
\hline
\end{tabular}

Source: the authors based on Furrer et al., 2008

Some other works that have been very influential in strategic management do not even appear in the list of works most cited in behavioral strategy: Rumelt (1974), Williamson (1975), 
Pfeffer and Salancik (1978), Uzzi (1997), and Thompson (1967). Their arguments on firm organization and relation to external markets have not had any significant citation impact among the field authors.

Finally, some works which have been key in the development of behavioral strategy are not ranked among the top studies for strategic management. A significant group of contributions to behavioral strategy have come in the new century. The number of citations they have received is small in relation to works that have been exposed for longer periods of time, as regards influence in the discipline. Also, as we discuss later, behavioral strategy is at the intersection of business strategy, economy, and cognitive sciences. Some works from the last three named disciplines have had a very influential role in the field but almost no impact on the strategy main discipline. Some missing works are less obvious. Levinthal and March (1993) about the pitfalls of learning organizations, is not in the top fifty list of strategic management in the first list and is only twenty-fourth in the second, but it sits in a prominent fifth position on the behavioral group list. Learning organizations has been a hot topic in the discipline for a long period of time, and March has been considered a key contributor.

\subsection{The intellectual structure of behavioral strategy.}

In the third step of the process we grouped the cited documents to build the map of the intellectual structure of behavioral strategy. For this purpose, we paired the cited works of the previous step according to their co-citation in the initial document's extraction. As explained in the methodology, we selected 41 papers (strongest cocitation 4) and used their co-citations for the analysis. As a result, 65 pairs of works were obtained.

Figure 2 shows the application of MDS to the selected documents, yielding excellent goodness of fit (stress $=0.032$ ). In the Figure, we have already labeled the factors of the subsequent analysis (see Table 8).

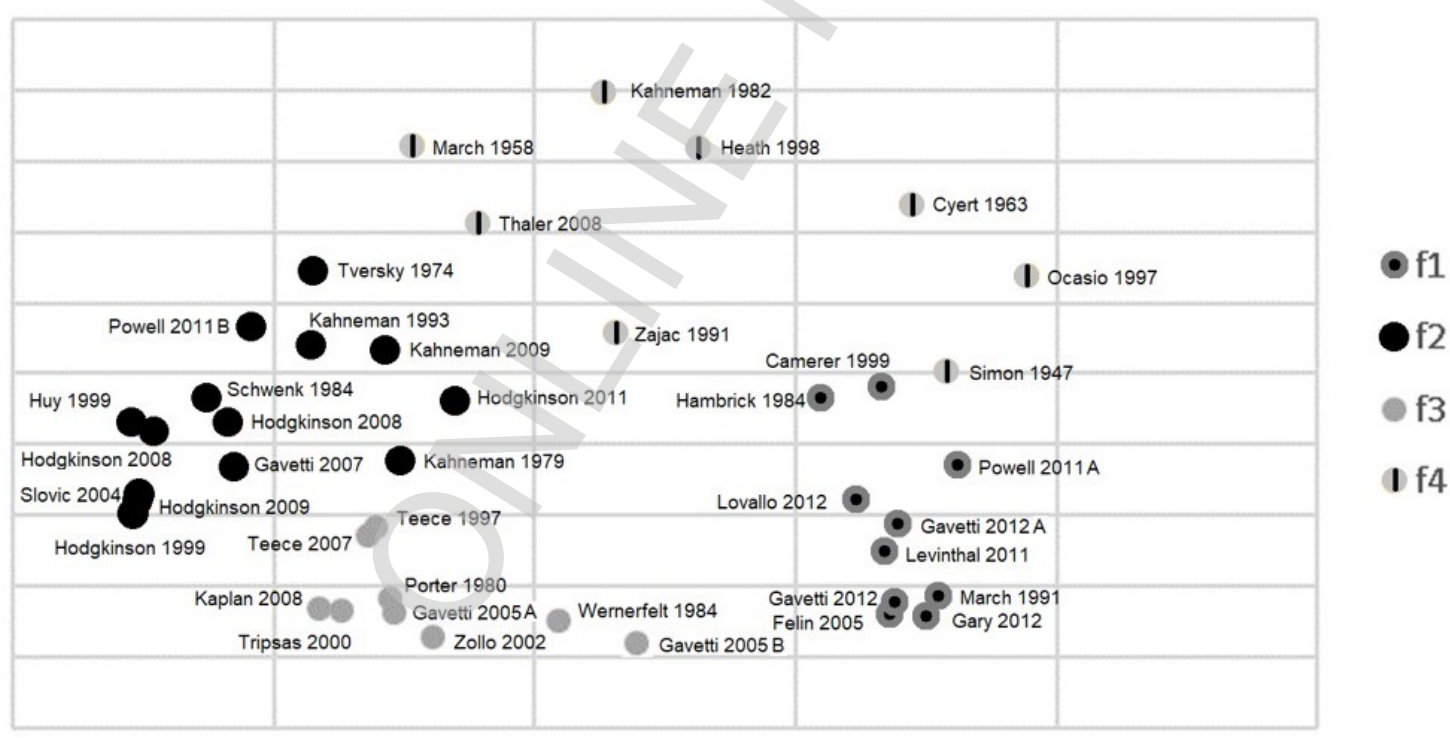

Figure 2 MDS two-component space.

Source: the author's

In order to check the robustness of our results and to have a more objective method than simple visual inspection to group the documents, we conducted a factor analysis (principal component extraction method) on the co-citation matrix confined to the 41 selected papers, extracting 4 factors and applying varimax rotation. The selection of 4 factors to be extracted was also supported on the scree plot/elbow curve (showing a dramatic drop off in the 5th eigenvalue compared to the 4th) and the total amount of explained variance reached $(61 \%)$ with the four factors retained (see Appendix). Table 7 presents the rotated factor matrix. 
Table 7 Rotated component matrix

\begin{tabular}{|c|c|c|c|c|}
\hline & \multicolumn{4}{|c|}{ Factor } \\
\hline & $\mathrm{F} 4$ & F3 & F2 & $\mathrm{F} 1$ \\
\hline Gary, M., 2012, V33, P1229, Strategic Manage J & 0,849 & & & \\
\hline Gavetti, G., 2012, V6, P1, Acad Manag Ann & 0,839 & & & \\
\hline Felin, T., 2005, V3, P441, Strategic Organization & 0,826 & & & \\
\hline Lovallo, D., 2012, V33, P496, Strategic Manage J & 0,824 & & & \\
\hline Levinthal, D., 2011, V32, P1517, Strategic Manage J & 0,813 & & & \\
\hline Gavetti, G., 2012, V23, P267, Organ Sci & 0,783 & & & \\
\hline Camerer, C., 1999, V89, P306, Am Econ Rev & 0,755 & & & \\
\hline March, J., 1991, V2, P71, Organ Sci & 0,689 & & & \\
\hline Hambrick, D., 1984, V9, P193, Acad Manage Rev & 0,679 & & & \\
\hline Powell, T., 2011, V32, P1369, Strategic Manage J & 0,506 & & & \\
\hline Slovic, P., 2004, V24, P311, Risk Anal & & 0,785 & & \\
\hline Hodgkinson, G., 1999, V20, P977, Strategic Manage J & 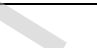 & 0,785 & & \\
\hline Hodgkinson, G., 2009, V42, P277, Long Range Plann & & 0,785 & & \\
\hline Tversky, A., 1974, V185, P1124, Science & & 0,780 & & \\
\hline Kahneman, D., 1993, V39, P17, Manage Sci & & 0,770 & & \\
\hline Kahneman, D., 2009, V64, P515, Am Psychol & & 0,757 & & \\
\hline Powell, T., 2011, V32, P1484, Strategic Manage J & & 0,722 & & \\
\hline Hodgkinson, G., 2008, V59, P387, Annu Rev Psychol & & 0,719 & & \\
\hline Hodgkinson, G., 2011, V32, P1500, Strategic Manage J & & 0,702 & & \\
\hline Schwenk, C., 1984, V5, P111, Strategic Manage J & & 0,696 & & \\
\hline Hodgkinson, G., 2008, V99, P1, Brit J Psychol & & 0,682 & & \\
\hline Huy, Q., 1999, V24, P325, Acad Manage Rev & & 0,635 & & \\
\hline Kahneman, D., 1979, V47, P263, Econometrica & & 0,572 & & \\
\hline Gavetti, G., 2007, V18, P523, Organ Sci & & 0,461 & & \\
\hline Tripsas, M., 2000, V21, P1147, Strategic Manage J & & & 0,800 & \\
\hline Kaplan, S., 2008, V51, P672, Acad Manage J & & & 0,782 & \\
\hline Gavetti, G., 2005, V16, P599, Organ Sci & & & 0,766 & \\
\hline Zollo, M., 2002, V13, P339, Organ Sci & & & 0,690 & \\
\hline Porter, M., 1980, Competitive Strategy & & & 0,664 & \\
\hline Wernerfelt, B., 1984, V5, P171, Strategic Manage J & & & 0,632 & \\
\hline Teece, D., 1997, V18, P509, Strategic Manage J & & & 0,609 & \\
\hline Gavetti, G., 2005, V26, P691, Strategic Manage J & & & 0,512 & \\
\hline Teece, D., 2007, V28, P1319, Strateg Manage J & & & 0,353 & \\
\hline Heath, C., 1998, V20, P1, Res Organ Behav & & & & 0,685 \\
\hline Kahneman, D., 1982, Judgment Uncertainty & & & & 0,663 \\
\hline March, J., 1958, Organizations & & & & 0,662 \\
\hline Thaler, R., 2008, Nudge Improving Deci & & & & 0,610 \\
\hline Ocasio, W., 1997, V18, P187, Strategic Manage J & & & & 0,609 \\
\hline Zajac, E., 1991, V16, P37, Acad Manage Rev & & & & 0,602 \\
\hline Simon, H., 1947, Adm Behav Study Deci & & & & 0,595 \\
\hline Cyert, R., 1963, Behav Theory Firm & & & & 0,533 \\
\hline
\end{tabular}

Source: the author's

Finally, we plotted the network map with the 65 pairs of 41 documents grouped by the factor analysis and proceeded to analyze the commonalities of each group. The graph can be seen in Figure 3. 


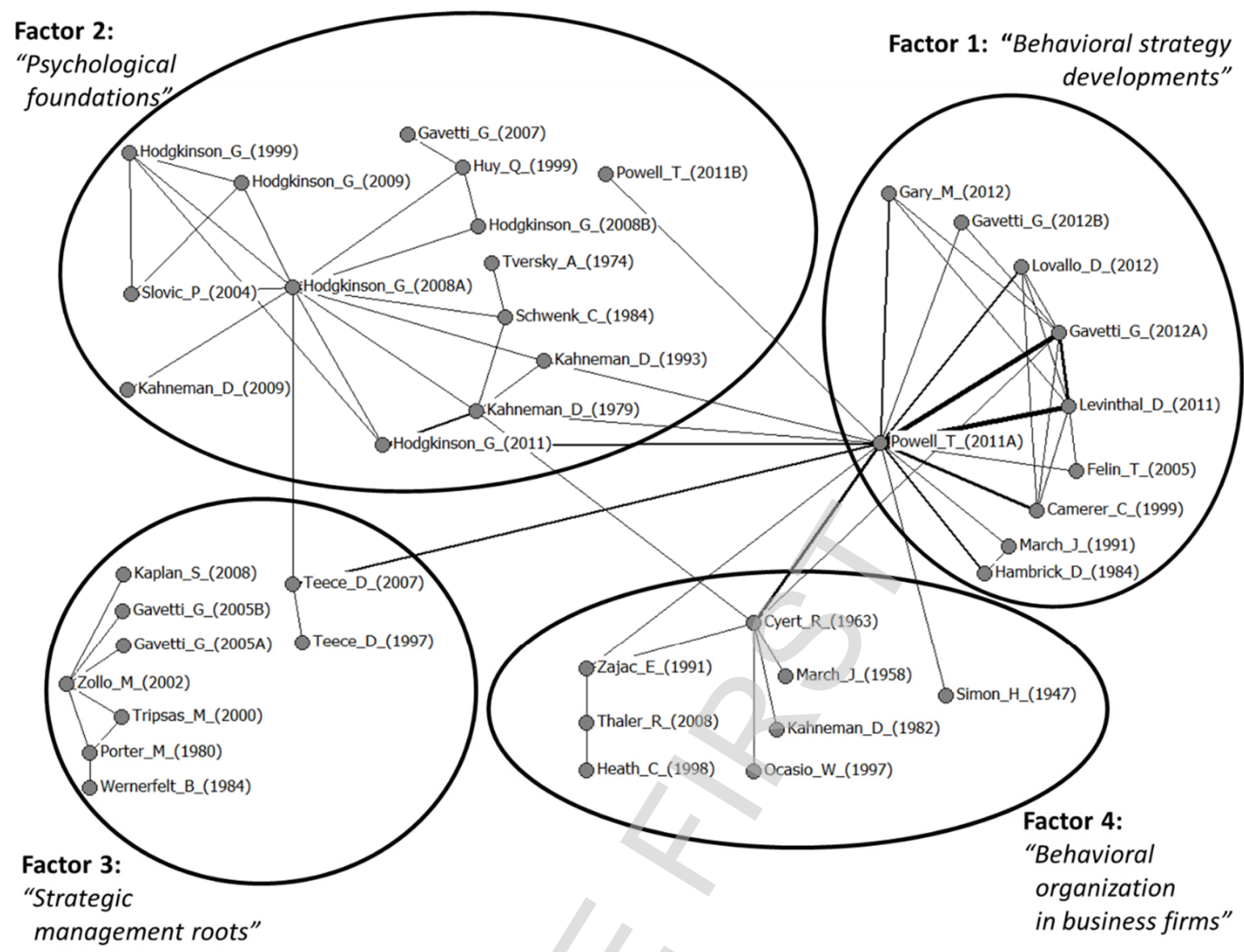

Figure 3 Group analysis Source: the author's

In the Figure we can identify the central node of the network and the four groups of woks determined by factor analysis. All four factors revolve around the central node, Powell et al., (2011), where behavioral strategy and the structure of the main areas of the field are defined (Powell et al., 2011). Having once defined the groups' structure, we labeled and analyzed the commonalties of the factors and their contribution to the intellectual structure (see Figure 4). 


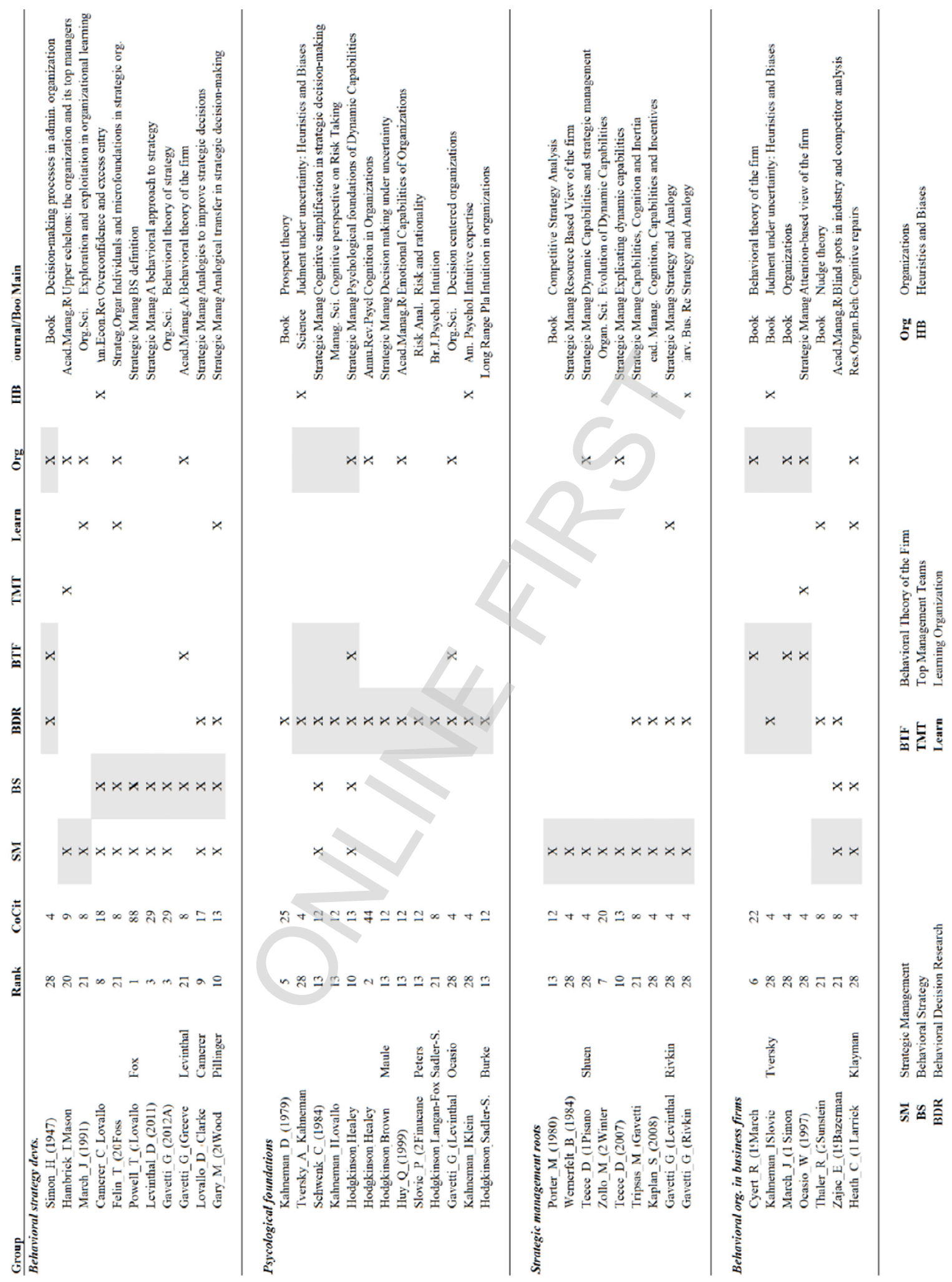

Figure 4 Works by topic research topic Source: the author's 


\subsubsection{Factor 1: Behavioral roots in business and economics}

The group gathers the works which set the pillars of behavioral aspects in economics and business. On average, it is a group with an older date of publication. Half (four out of eight) are books rather than articles. It is a group with higher number of co-citations with the central node, indicating which is not specifically about behavioral strategy but can be considered as its precursor.

It is made out of three branches or subgroups. In the first, standing alone, there is the seminal work of Simon (1947) about decision-making processes in administrative organizations. It introduces the concept of satisficing opposed to the traditional economic optimization, as the criteria for decision-making. The book was of paramount influence for the Nobel Prize in Economic Sciences to Simon in 1978. The second links three top pillars of behavioral economics: Zajac and Bazerman (1991), blind spots in industry and competitor analysis, Thaler and Sunstein (2008), nudge theory and Heath, Larrick and Klayman, (1998), cognitive repairs. Finally, four key works on firm behavior are grouped around the principles of the Carnegie School: Cyert and March (1963), behavioral theory of the firm, March and Simon (1958), Organizations, Kahneman, Slovic and Tversky, (1982) judgement under uncertainty and Ocasio (1997) Attention-based view of the firm.

\subsubsection{Factor 2: Main stream strategic management influences}

The group gathers the strategic management works that have influenced the developments of behavioral strategy most. The main branch is isolated and has no link with any of the other works. The other branch gathers the two main works of Teece which leads the "Dynamic Capabilities" approach in strategic management. Teece (2007) is the only work linking with the rest of the pack, but it pairs with the two most influential works of the study, the central nodes of factors 3 and 4.

The influence and some degree of interrelationship between strategic management and behavioral strategy are clear. However, the lack of pairing between this group and the central node and the remaining factor 4 works indicate that the latter should be considered more an independent topic which complements the former than a subfield of the main strategic management stream.

\subsubsection{Factor 3: "Psychological foundations"}

This group is the most populated. We have labeled it "psychological foundations", as it is a group that contains the main works in the psychology discipline influencing strategic management. It is located on the left side of the chart and takes fourteen works of twenty different authors. This group has a central node (Hodgkinson \& Healey, 2008) which reviews all major developments from 2000 to early 2007 in the psychological analysis of cognition in organizations. This node is co-cited with ten works of the cluster, which indicates its central role but has no direct co-citation link with the main central node of the network.

In the "Psychological Foundations" group, there are five works of G.P. Hodgkinson, and three of D. Kahneman, making these authors the key influencers of the discipline from the group perspective.

Three subgroups can be identified:

The "decision-making" subgroup covers key aspects of this cognitive process, from intuition (Hodgkinson, G. P., Sadler-Smith, E., Burke, L. A., Claxton, G., \& Sparrow, P. R., 2009) to risk and uncertainty influence (Hodgkinson, G. P., Bown, N. J., Maule, A. J., Glaister, K. W., \& Pearman, A. D., 1999; Slovic, P., Finucane, M. L., Peters, E., \& MacGregor, D. G., 2004). The three works together with the central node of the cluster are co-cited in pairs, making this a very connected and cohesive subgroup. Also, on the role of intuition in heuristics and biases (HB) and naturalistic decision making (NDM) is the article from Kahneman and Klein (2009) which is not co-cited with the members of this cluster but is with the central node.

The second subgroup applies the psychology developments to the behavior of organizations. Gavetti, Levinthal and Ocasio (2007) point out that the defining commitment to decision-centered view of organizations of the Carnegie School had given way to learning, routines and an increasing focus on change and adaptation and argue to regain the initial focus and incorporate major developments post-Carnegie both within organization theory and in the behavioral and social sciences broadly. Quy Huy takes emotional intelligence individual behaviors and links them with organization behavior specifically in change situations to develop the concept of emotional capability (Huy, 1999). Finally, Hodgkinson, Langan-Fox and Sadler-Smith (2008) introduce intuition as a concept which was underdeveloped but had high potential in exploring behaviors. 
We have named the third subgroup "cognitive process". It includes three works that touch on some key biases of the business decision-making psychological process: simplification and judgement under uncertainty (Kahneman \& Lovallo, 1993; Schwenk, 1984; Tversky \& Kahneman, 1974). The first analyzes executive biases when they consider problems as unique, taking cautious or optimistic attitudes based on plans instead of considering previous experiences. Schwenk applies the simplification biases studied by psychologists to executive decision making and its implications. The last of the three is one of the most cited articles in cognitive bias used by researchers to explore behavioral sciences.

As we have mentioned, the central node of the group is not connected to the central node of the structure. This is done by three key works which act as the intellectual bridge to the rest of the discipline. Kahneman and Tversky (1979) prospect theory, already described as one of the key influencers, is co-cited with the central node of the network, linked with Cyert and March (1963) the central node of factor 4 and with four other works of factor 2 making this work a clear link between three groups of documents. Hodgkinson and Healey (2011), as previously mentioned, look at the psychological foundations of dynamic capabilities. The third link is Kahneman and Lovallo's (1993) work on a cognitive perspective on risk taking.

\subsubsection{Factor 4: "Behavioral strategy developments"}

This factor groups the set of works that have developed behavioral strategy. The central node is part of the group and as stated before marks the definition of the term and sets the basic principles of the discipline. All works in the factor group are co-cited with it. Four of the works were published before the central node. Another five came out subsequently and are already under its umbrella. Six frequently cited works belong to the group, despite having been published recently.

Within the group, two stands as a separate branch: Hambrick and Mason (1984) look at strategic behavior of top management and March (1991) at a learning organization. Both continue the research line of the behavioral theory of the firm, early pointing to the implications on the business strategy and somehow bridge with the works of factor 1 despite not being co-cited with any of them.

Building bridges with factor 3, Camerer and
Lovallo (1999) work on the influence of one of the most common bias in decision-making, overconfidence, in the classic strategic decisions in new market entries. It is one of the most cited articles and it is co-cited with a few other works of the factor pointing to the strong influence exerted in the discipline.

There is another key element of this factor also published before 2011. It is an editorial essay by Felin and Foss (2005) drawing attention to the emphasis put on the organization in strategic organizational research, neglecting the role of individuals who take decisions on individual mechanisms. The focus of the essay is on the organizational capabilities-based literature in strategic management, which serves as a specific example of a more general problem: the lack of attention to individuals in the strategic organizational approach.

The other five works are all inter co-cited particularly having a particularly strong co-citation with the central node, Levinthal (2011) and Gavetti (2012), all three acting as the cornerstones of the definition of the discipline. One year later, Gavetti, with Greeve, Levinthal and Ocasio (2012), reinforced the concepts focusing on the firm ecosystem. Another two articles forming part of this group were published in 2012 (Gary, M. S., Wood, R. E., \& Pillinger, T., 2012; Lovallo, D., Clarke, C., \& Camerer, C., 2012). Both look at the use of analogies, a very common tool used in taking strategic decisions under uncertainties and novel situations and explore its advantages and pitfalls. As we saw in the previous factor, the cognitive process of analogies in decision-making is featured in other groups of the structure.

\section{Latest contributions}

As we will mention in the conclusions a potential limitation of this study is the influence of time in the methodology. Recent published articles may lack a number of cites according to their potential future influence.

During the last few years, a few works on behavioral strategy have been published. However, they have not received enough citations to be part of this study. We have considered some of them have potential to be among the most influencers in the near future.

In an editorial commentary, Foss (2020) deals with the findings that COVID-19 crisis has provided to the field. 
Behavioral strategy is uniquely situated in terms of providing a psychologically based interpretive lens that could lend great insight into decision making in extreme conditions. However, the disruption also points to weakness in current behavioral strategy thinking, notably with respect to the role of models vis-à-vis judgment in strategic decision making, the deeply social (political, institutional) nature of strategy making, and the treatment of fundamental uncertainty. (p. 1322)

Some of the contributions work on the linkage of psychological developments and the impact on decision making in general and strategic decisions in particular. Some examples are Menon (2018) work on strategic mental models, Healey and Hodgkinson (2017) on executive skills of emotion regulation and the real impact of strategic dissent on organizational outcomes (Samba, C., Van Knippenberg, D., \& Miller, C. C., 2018).

Another significant recent development in this area is the affect-cognitive theory by Cristofaro (2019; 2020) overcoming the thinking-feeling dichotomy that has predominated in the study of management decisions. The theory is beneficial for behavioral strategy, offering the needed assumptions to intertwine human cognition, emotions, and social behavior.

Finally, there is a group of works recently published that start to be cited by behavioral strategy articles influencing the development of the discipline from the organizational behavior perspective. They do it both in strategy formulation and strategy implementation phases. These are the cases of the analysis of upward social comparison (Obloj \& Zenger, 2017), the research on subsidiary performance feedback and internal governance in multiunit firms (Sengul \& Obloj, 2017), mix of feelings and emotions influencing leadership (Rothman \& Melwani, 2017) and the exploration on how different aspects of diversity influence constructive politics and the extent to which the latter contribute to decision performance, namely, decision success and decision pace (Elbanna, 2018).

We conclude that the first work is a potential future candidate to Factor 1, the second group would be for Factor 2 and last group clearly will in future research with this approach be candidates to Factor 4.

\section{Conclusions}

The objective of this article was to organize and display the intellectual structure of behavioral strategy discipline born from the integration of knowledge developed in very different scientific areas. The formulation of business strategies is about decision making, and the developments on cognitive decision making made by psychology and neuroscience researchers has been integrated in strategic management processes research as it has been done with other economic and business disciplines. Due to the youth of this research field and the complexity and variety of its sources, the effort to articulate its structure had not been carried out until now in a systematic way. This paper covers the gap using a proven objective and replicable methodology that had not been used in this area yet.

Several findings have been presented and discussed in the previous section. There are some conclusions which stem from these findings.

There are four clear solid research pillars of the field: behavioral organization, strategic management, cognitive psychology and behavioral strategy seminal papers. Out of the four groups, strategic management is the one with a lesser degree of influence, interaction and integration. Key works in strategic management are not among the most cited in behavioral strategy reference papers and the main stream of strategic management research has a marginal influence of behavioral strategy. This field is not being even identified as part of the intellectual structure of strategic management by the key papers addressing the topic (Furrer et al., 2008; Guerras-Martín et al., 2014; Nerur et al., 2008; Ramos-Rodríguez \& Ruíz-Navarro, 2004). At this point in time we can conclude that behavioral strategy should not be considered a field of strategic management but rather a complementary discipline.

Another finding of the analysis relates to the development structure of behavioral strategy. Rather than building a solid theoretical corpus research focus has been put on particular areas and specific situations of the business strategy process of formation and implementation. The aim of researchers has pointed towards avoiding the pitfalls and mistakes caused by cognitive processes and biases. Although some works are starting to fill the gap the most influential works are very much concentrated in these lines of research. There is a wide area still open for research and development of the cognitive decision-making processes characteristics implications in business strategies. These areas include but are not limited to strategy elements such as: 
- Behavioral approach to market analysis

- Strategic behavior of competition

- Behavioral competitive advantages

- Stakeholders relationships and interactions

This study has its limitations, particularly in regard to the citation methodology. However, the characteristics of the approach limited impact. Citation methodology is criticized because the value of each citation is considered the same. In our case, we worked with more than two thousand unique citations and more than one hundred and fifty thousand co-citation pairs. The sheer volume helped to soften the impact of the limitation. Moreover, we selected a reasonable number of documents with a co-citation strength 4 or above removing most of the noise created by nonsignificant citations.

Citation technique is influenced by time. The more recent the work the lesser the opportunities to be cited. However, as the object of this study is to determine the degree of influence, this effect correlates with the fact that influence is determined by the work being recognized and cited, and recent works have had less time to influence researchers over a period of time.

Finally, we think this work should help future research by providing the picture of the current situation of the discipline and the main pillars to build on. We also intend to extend the contribution to the practitioner's community concerned and engaged in a topic which has such a huge economic impact for firms and industries. The findings should help researchers and practitioners alike in their quest to continue the progress of one of the most impacting developments around the strategic management process.sM

\section{References}

Bergh, D. D., Perry, J., \& Hanke, R. (2006). Some predictors of SMJ article impact. Strategic Management Journal, 27(1), 81-100. https://doi.org/10.1002/smj.504

Bromiley, P. (2005). The behavioral foundations of strategic management. Blackwell Publishing. Oxford, UK.

Camerer, C., \& Lovallo, D. (1999). Overconfidence and excess entry: An experimental approach. American Economic Review, 89(1), 306-318. https://doi.org/10.1257/aer.89.1.306

Cole, J., \& Cole, S. (1971). Measuring the quality of sociological research: Problems in the use of the" science citation index". The American Sociologist, 6(1), 23-29.

Cristofaro, M. (2019). The role of affect in management decisions: A systematic review. European Management Journal, 37(1), 6-17. https://doi.org/10.1016/j.emj.2018.12.002
Cristofaro, M. (2020). "I feel and think, therefore I am": An affect-cognitive theory of management decisions. European Management Journal, 38(2), 344-355. https://doi.org/10.1016/j.emj.2019.09.003

Cyert, R. M., \& March, J. G. (1963). A behavioral theory of the firm. Prentice-Hall. Englewood Cliffs, NJ.

Dobni, B., Dobni, D., \& Luffman, G. (2001). Behavioral approaches to marketing strategy implementation. Marketing Intelligence \& Planning, 19(6), 400-408. https://doi.org/10.1108/02634500110405405

Elbanna, S. (2018). The constructive aspect of political behavior in strategic decision-making: The role of diversity. European Management Journal, 36(5), 616626.

https://doi.org/10.1016/j.emj.2018.06.006

Felin, T., \& Foss, N. J. (2005). Strategic organization: A field in search of micro-foundations. Strategic Organization, 3(4), 441-455. https://doi.org/10.1177/1476127005055796

Foss, N. J. (2020). Behavioral strategy and the COVID-19 disruption. Journal of Management, 46(8), 1322-1329. https://doi.org/10.1177/0149206320945015

Furrer, O., Thomas, H., \& Goussevskaia, A. (2008). The structure and evolution of the strategic management field: A content analysis of 26 years of strategic management research. International Journal of Management Reviews, 10(1), 1-23.

https://doi.org/j.1468-2370.2007.00217.x

García-Lillo, F., Úbeda-García, M., \& Marco-Lajara, B. (2016). The intellectual structure of research in hospitality management: A literature review using bibliometric methods of the journal international journal of hospitality management. International Journal of Hospitality Management, 52, 121-130. https://doi.org/10.1016/j.ijhm.2015.10.007

Gary, M. S., Wood, R. E., \& Pillinger, T. (2012). Enhancing mental models, analogical transfer, and performance in strategic decision making. Strategic Management Journal, 33(11), 1229-1246. https://doi.org/10.1002/smj.1979

Gavetti, G. (2012). PERSPECTIVE-Toward a behavioral theory of strategy. Organization Science, 23(1), 267285. https://doi.org/10.1287/orsc.1110.0644

Gavetti, G., Greve, H. R., Levinthal, D. A., \& Ocasio, W. (2012). The behavioral theory of the firm: Assessment and prospects. The Academy of Management Annals, 6(1), 1-40. https://doi.org/10.1080/19416520.2012.656841

Gavetti, G., Levinthal, D., \& Ocasio, W. (2007). Perspective-Neo-carnegie: The carnegie school's past, present, and reconstructing for the future. Organization Science, 18(3), 523-536. https://doi.org/10.1287/orsc.1070.0277

Guerras-Martín, L. Á, Madhok, A., \& Montoro-Sánchez, Á. (2014). The evolution of strategic management research: Recent trends and current directions. $B R Q$ Business Research Quarterly, 17(2), 69-76. https://doi.org/10.1016/j.brq.2014.03.001

Hambrick, D. C., \& Mason, P. A. (1984). Upper echelons: The organization as a reflection of its top managers. Academy of Management Review, 9(2), 193-206. https://doi.org/10.5465/amr.1984.4277628

Healey, M. P., \& Hodgkinson, G. P. (2017). Making strategy hot. California Management Review, 59(3), 109-134. https://doi.org/10.1177/0008125617712258 
Heath, C., Larrick, R. P., \& Klayman, J. (1998). Cognitive repairs: How organizational practices can compensate for individual shortcomings. Research in Organizational Behavior, 20, 1-37.

Hodgkinson, G. P., Bown, N. J., Maule, A. J., Glaister, K. W., \& Pearman, A. D. (1999). Breaking the frame: An analysis of strategic cognition and decision making under uncertainty. Strategic Management Journal, 20(10), 977-985

https://doi.org/10.1002/(SICl)10970266(199910)20:103.0.CO:2-X

Hodgkinson, G. P., \& Healey, M. P. (2008). Cognition in organizations. Annual Review of Psychology, 59, 387417. https://doi.org/10.1146/annurev.psych.59.103006.093612

Hodgkinson, G. P., \& Healey, M. P. (2011). Psychological foundations of dynamic capabilities: Reflexion and reflection in strategic management. Strategic Management Journal, 32(13), 1500-1516. https://doi.org/10.1002/smj.964

Hodgkinson, G. P., Langan-Fox, J., \& Sadler-Smith, E. (2008). Intuition: A fundamental bridging construct in the behavioural sciences. British Journal of Psychology, 99(1), 1-27. https://doi.org/10.1348/000712607X216666

Hodgkinson, G. P., Sadler-Smith, E., Burke, L. A., Claxton, G., \& Sparrow, P. R. (2009). Intuition in organizations: Implications for strategic management. Long Range Planning, 42(3), 277-297. https://doi.org/10.1016/j.Irp.2009.05.003

Huy, Q. N. (1999). Emotional capability, emotional intelligence, and radical change. Academy of Management Review, 24(2), 325-345. https://doi.org/10.5465/amr.1999.1893939

Kahneman, D., \& Klein, G. (2009). Conditions for intuitive expertise: A failure to disagree. American Psychologist 64(6), 515-526. https://doi.org/10.1037/a0016755

Kahneman, D., \& Lovallo, D. (1993). Timid choices and bold forecasts: A cognitive perspective on risk taking. Management Science, 39(1), 17-31. https://doi.org/10.1287/mnsc.39.1.17

Kahneman, D., Slovic, P., \& Tversky, A. (Eds.). (1982). Judgment under uncertainty: Heuristics and biases. Cambridge University Press. UK https://doi.org/10.1017/CBO9780511809477

Kahneman, D., \& Tversky, A. (1979). Prospect theory: An analysis of decisions under risk. Econometrica, 47(2), 263-292. https://doi.org/10.2307/1914185

Levinthal, D. A. (2011). A behavioral approach to strategywhat's the alternative? Strategic Management Journal, 32(13), 1517-1523. https://doi.org/10.1002/smj.963

Levinthal, D. A., \& March, J. G. (1993). The myopia of learning. Strategic Management Journal, 14(S2), 95112. https://doi.org/10.1002/smj.4250141009

Loock, M., \& Hinnen, G. (2015). Heuristics in organizations: A review and a research agenda. Journal of Business Research, 68(9), 2027-2036. https://doi.org/10.1016/i.jbusres.2015.02.016

Lovallo, D., Clarke, C., \& Camerer, C. (2012). Robust analogizing and the outside view: Two empirical tests of case-based decision making. Strategic Management Journal, 33(5), 496-512. https://doi.org/10.1002/smj.962
Lovallo, D., \& Sibony, O. (2010). The case for behavioral strategy. McKinsey Quarterly, 2(1), 30-43.

March, J. G. (1991). Exploration and exploitation in organizational learning. Organization Science, 2(1), 7187. https://doi.org/10.1287/orsc.2.1.71

March, J. G., \& Simon, H. A. (1958). Organizations. Wiley. Oxford, England.

Menon, A. (2018). Bringing cognition into strategic interactions: Strategic mental models and open questions. Strategic Management Journal, 39(1), 168192.

https://doi.org/10.1002/smj.2700

Nag, R., Hambrick, D. C., \& Cheng, M. (2007). What is strategic management, really? Inductive derivation of a consensus definition of the field. Strategic Management Journal, 28(9), 935-955.

https://doi.org/10.1002/smi.615

Nerur, S. P., Rasheed, A. A., \& Natarajan, V. (2008). The intellectual structure of the strategic management field: An author co-citation analysis. Strategic Management Journal, 29(3), 319-336. https://doi.org/10.1002/smj.659

Obloj, T., \& Zenger, T. (2017). Organization design, proximity, and productivity responses to upward social comparison. Organization Science, 28(1), 1-18. https://doi.org/10.1287/orsc.2016.1103

Ocasio, W. (1997). Towards an attention-based view of the firm. Strategic Management Journal, 18(S1), 187-206. https://doi.org/10.1002/(SICl)10970266(199707)18:1+3.0.CO;2-K

Pettigrew, A., Thomas, H., \& Whittington, R. (2002). Strategic management: The strengths and limitations of a field. In A. Pettigrew, H. Thomas \& R. Whittington (Eds.), Handbook of strategy and management (pp. 330). Sage. London.

Pfeffer, J., \& Salancik, G. R. (1978). The external control of organizations: A resource dependence perspective. Harper \& Row. New York.

Porter, M. E. (1980). Competitive strategy: Techniques for analyzing industries and competitors. Free Press. New York.

Powell, T. C., Lovallo, D., \& Fox, C. R. (2011). Behavioral strategy. Strategic Management Journal, 32(13), 13691386. https://doi.org/10.1002/smj.968

Ramdhani, A., Ramdhani, M. A., \& Amin, A. S. (2014). Writing a literature review research paper: A step-bystep approach. International Journal of Basics and Applied Sciences, 3(1), 47-56.

Ramos-Rodríguez, A., \& Ruíz-Navarro, J. (2004). Changes in the intellectual structure of strategic management research: A bibliometric study of the strategic management journal, 1980-2000. Strategic Management Journal, 25(10), 981-1004. https://doi.org/10.1002/smj.397

Rothman, N. B., \& Melwani, S. (2017). Feeling mixed, ambivalent, and in flux: The social functions of emotional complexity for leaders. Academy of Management Review, 42(2), 259-282. https://doi.org/10.5465/amr.2014.0355

Rumelt, R. P. (1974). Strategy, structure, and economic performance. Harvard University Press. Cambridge, MA. 
Samba, C., Van Knippenberg, D., \& Miller, C. C. (2018). The impact of strategic dissent on organizational outcomes: A meta-analytic integration. Strategic Management Journal, 39(2), 379-402. https://doi.org/10.1002/smj.2710

Schwenk, C. R. (1984). Cognitive simplification processes in strategic decision-making. Strategic Management Journal, 5(2), 111-128. https://doi.org/10.1002/smj.4250050203

Sengul, M., \& Obloj, T. (2017). Better safe than sorry: Subsidiary performance feedback and internal governance in multiunit firms. Journal of Management, 43(8), 2526-2554. https://doi.org/10.1177/0149206316677298

Simon, H. A. (1947). Administrative behavior: A Study of Decision-making Processes In Administrative Organization. Macmillan. New York.

Slovic, P., Finucane, M. L., Peters, E., \& MacGregor, D. G. (2004). Risk as analysis and risk as feelings: Some thoughts about affect, reason, risk, and rationality. Risk Analysis, 24(2), 311-322. https://doi.org/j.0272-4332.2004.00433.x

Small, H. (1973). Co-citation in the scientific literature: A new measure of the relationship between two documents. Journal of the American Society for Information Science, 24(4), 265-269. https://doi.org/10.1002/asi.4630240406

Smith, L. C. (1981). Citation analysis. Library Trends, 30(1), 83-106.

Snyder, H. (2019). Literature review as a research methodology: An overview and guidelines. Journal of Business Research, 104, 333-339. https://doi.org/10.1016/j.jbusres.2019.07.039

Teece, D. J. (2007). Explicating dynamic capabilities: The nature and microfoundations of (sustainable) enterprise performance. Strategic Management Journal, 28(13), 1319-1350.

https://doi.org/10.1002/smj.640
Thaler, R. H. (2005). Advances in behavioral finance. Princeton University Press. NJ.

Thaler, R. H., \& Sunstein, C. R. (2008). Nudge: Improving Decisions About Health, Wealth, and Happiness. Yale University Press. New Haven \& London.

Thompson, J. D. (1967). Organizations in Action: Social Science Bases of Administration. McGraw-Hill. New York.

Tversky, A., \& Kahneman, D. (1974). Judgment under uncertainty: Heuristics and biases. Science, 185(4157), 1124-1131. https://doi.org/10.1126/science.185.4157.1124

Uzzi, B. (1997). Social structure and competition in interfirm networks: The paradox of embeddedness. Administrative Science Quarterly, 42(1), 35-67. https://doi.org/10.2307/2393808

Volberda, H. W. (2004). Crisis in strategy: Fragmentation, integration or synthesis. European Management Review, 1(1), 35-42. https://doi.org/10.1057/palgrave.emr.1500013

Williamson, O. E. (1975). Markets and hierarchies: Analysis and Antitrust Implications. Free Press. New York.

Zajac, E. J., \& Bazerman, M. H. (1991). Blind spots in industry and competitor analysis: Implications of interfirm (mis) perceptions for strategic decisions. Academy of Management Review, 16(1), 37-56. https://doi.org/10.5465/amr.1991.427899010.5465/amr. $\underline{1991.4278990}$ 
Urío et al. The intellectual structure of behavioral strategy: a bibliometric study

\section{Appendix}

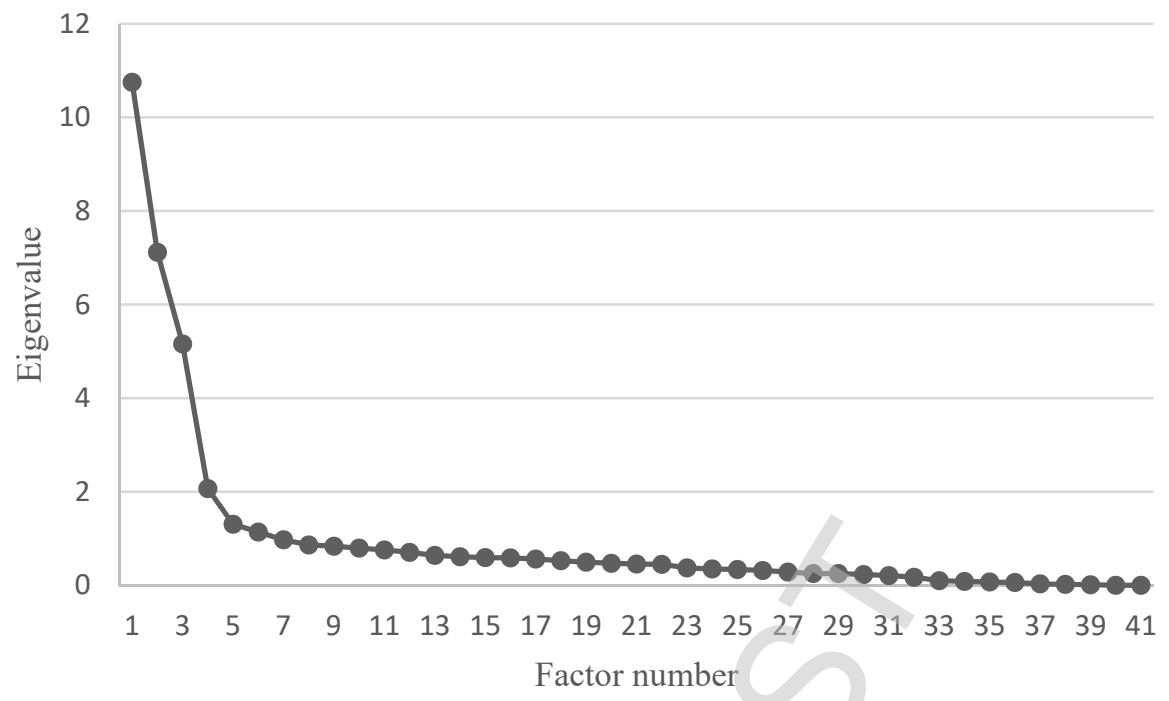

Figure Scree plot / Elbow curve Source: the author's

Table Total Variance explained.

\begin{tabular}{|c|c|c|c|c|c|c|c|c|c|}
\hline \multirow[t]{2}{*}{ Factor } & \multicolumn{3}{|c|}{ Initial eigenvalues } & \multicolumn{3}{|c|}{$\begin{array}{c}\text { Extraction Sums of Squared } \\
\text { Loadings }\end{array}$} & \multicolumn{3}{|c|}{ Rotation Sums of Squared Loadings } \\
\hline & Total & $\%$ of Variance & $\begin{array}{c}\% \\
\text { Cumulative }\end{array}$ & Total & $\begin{array}{l}\% \text { of } \\
\text { Variance }\end{array}$ & $\begin{array}{c}\% \\
\text { Cumulative }\end{array}$ & Total & $\begin{array}{c}\% \text { of } \\
\text { Variance }\end{array}$ & $\%$ Cumulative \\
\hline 1 & 10,752 & 26,223 & 26,223 & 10,752 & 26,223 & 26,223 & 8,078 & 19,703 & 19,703 \\
\hline 2 & 7,188 & 17,361 & 43,585 & 7,118 & 17,361 & 43,585 & 7,975 & 19,451 & 39,154 \\
\hline 3 & 5,157 & 12,579 & 56,164 & 5,157 & 12,579 & 56,164 & 5,230 & 12,757 & 51,911 \\
\hline 4 & 2,066 & 5,040 & 61,204 & 2,066 & 5,040 & 61,204 & 3,810 & 9,293 & 61,204 \\
\hline
\end{tabular}

$\triangle$ Correspondence

\section{Santiago Urío}

Department of Business Management, Universidad Pontificia Comillas, ICADE

calle Alberto Aguilera 23, 28015 Madrid, Spain

E-mail: surio@comillas.edu 